\title{
МИГРАЦИИ КАК ФАКТОР ФОРМИРОВАНИЯ ПОЛИЭТНИЧНОГО НАСЕЛЕНИЯ МОРДОВИИ: ИСТОРИЧЕСКИЙ АСПЕКТ
}

В статье на основе, главным образом, неопубликованных источников, выявленных в архивах и впервые вводимых в научный оборот, показана роль представителей зарубежья в формировании полиэтничности Мордовии, ныне республики, входящей в Приволжский федеральный округ Российской Федераџии. Проанализированы истоки полиэтничности мордовского края, описаны основные тенденции развития мигращионных прочессов. На основе имеющихся научных исследований и данных государственной статистики рассмотрень основнье характеристики пространственной мобильности населения мордовского края со второй половины XIX в. до начала XX в. Полиэтничность республики подтверждают данные всероссийской переписи населения, согласно которой на 2010 год в Мордовии проживало население 119 национальностей. Приведень статистические данные переписи населения Российской Империи 1897 года с иностранным контингентом в губерниях Мордовии и данные о составе населения по переписи 1939 года. Авторами установлено, что формирование полиэтничности Мордовской Республики складывалось под воздействием важнейших исторических событий, происходивших как в Европе, так и в России. Эти события обуславливали появление факторов, способствовавщих миграчионным процессам и менявших этнический состав населения Мордовии. Среди них, например, строительство Казанской железной дороги, которое привело к индустриализации и развитию промышленных предприятий в регионе, притоку иностранных специалистов и рабочих по обслуживанию оборудования, события Первой мировой войны, вызвавшие миграции из западных стран в регионы России, расположение лагерей с военнопленными на территории республики, брачная миграция и др. Авторами приведены исторические данные о получении иностраниами русского подданства в Мордовии.

Ключевые слова: полиэтничный регион, этническая структура, беженцы, национальный состав, народы зарубежья, миграция населения

Ссылка при цитировании: Никонова Л.И., Минакова А.И. Миграции как фактор формирования полиэтничного населения Мордовии: исторический аспект // Вестник антропологии, 2021. № 2. С. 230-240.

Никонова Людмила Ивановна - д.и.н., профессор, ведущий научный сотрудник отдела этнологии и межэтнических отношений, НИИ гуманитарных наук при Правительстве Республики Мордовия (430005 Саранск, ул. Л. Толстого, д. 3). Эл. почта: congress7@list.ru. ORCID: htpps:// orcid.org/0000-0003-4327-9534

Минакова Альбина Ирфановна - старший преподаватель, Московский государственный технический университет имени Н.Э. Баумана (105005 Москва, 2-я Бауманская, 5). Эл. почта: mau@ bmstu.ru. ORCID: htpps://orcid.org/0000-0003-3938-7276 
В качестве объекта исследования авторы настоящей работы выбрали миграционные процессы в Республике Мордовия в период со второй половины XIX до начала $\mathrm{XX}$ в. Этот регион, являясь одним из субъектов Российской Федерации, наделенных обширными территориями, развитой промышленностью, хорошей экологией, культурными памятниками (Никонова 2007; Gurko et al. 2019), характеризуется исторически сложившейся полиэтничной структурой населения. Основной задачей исследования является выявление истоков формирования полиэтничности мордовского края, роли в этом процессе зарубежных народов, изучение факторов, повлиявших на современный этнический состав населения, этнокультурную динамику, социальные условия адаптации мигрантов. Формирование полиэтничности республики складывалось в результате разных событий, наиболее значимыми среди которых были приток беженцев из западных стран во время Первой мировой войны и организация здесь лагерей для военнопленных. Многие беженцы и освободившиеся военнопленные разных национальностей остались на территории республики.

Данный вопрос затрагивался учеными ранее лишь фрагментарно в контексте иных исследовательских задач. О положении беженцев в Мордовии писали А.Н. Курцев (Куриеев 1999), В. В. Хасин (Хасин 1999), П. Гетрелл (Гетрелл 2001: 46-72), применение труда военнопленных в России освещено в работах В.Р. Копылова (Копьлов 1977: 61-69), И.Б. Ниманова (Ниманов 2009) и Н. Н. Терешиной (Терешина 2017). Однако в приведенных публикациях не прослеживается влияние беженцев и военнопленных на формирование многоэтничности и динамику численности представителей разных национальностей в мордовском крае. Научная новизна статьи заключается в анализе материалов архивов по беженцам и военнопленным первой империалистической войны (1914-1918 г.). Значимыми источниками в рамках исследования стали также статистические данные, содержащиеся в Итогах переписей 1897 г. и 1939 г., использование которых позволило создать целостную картину истоков формирования многонациональности мордовского края.

Строительство железной дороги из Москвы в Казань стало определяющим фактором особенностей новейшей истории Мордовии. Масштабное строительство железнодорожных линий оказало значительное влияние на развитие экономической, торговой, общественно-политической и социально-культурной жизни мордовского края. Запуск линий Рузаевка - Пенза, Рузаевка - Сызрань, Ромоданово - Нижний Новгород и изменение инфраструктуры в регионе привели к появлению нового слоя жителей, связанных с железнодорожным предпринимательством: железнодорожных рабочих, техников, появилась новая отрасль хозяйственной деятельности - железнодорожные перевозки. Одновременно улучшалось социально-экономическое положение края, велись работы по строительству крупных городов, среди которых Ардатов, Инсар, Краснослободск, Саранск. Постепенно Ардатов, Инсар, Краснослободск, Саранск превращались в торгово-промышленные центры, ощутимо ускорился процесс урбанизации в регионе. Так, городское население в Мордовии в период с 1860 по 1897 г. увеличилось на 6,4 тыс. человек и насчитывало более 46 тыс., т.е. примерно 4\% всего населения, тогда как в России в среднем городское население составляло около 13\%. К примеру, в Саранске в период с 1867 по 1916 гг. население увеличилось с 14,2 тыс. до 18 тыс. человек (Петербургский и др. 2003: 33). 
Согласно Первой всеобщей переписи населения Российской империи 1897 г., на всей территории Мордовии проживал 1062913 чел. (Ломшин и др. 2007: 159-160). Положительный прирост населения (Grech 2019) указывает на то, что численность его росла благодаря мигрантам, появившимся в регионе. Чтобы получить представление об этническом составе жителей региона обратимся к указанной переписи и проанализируем статистические данные о владении родным языком в Пензенской (Краснослободский, Саранский уезды), Симбирской (Ардатовский), Нижегородской и Тамбовской (Темниковский уезд) губерниях, так как до 1928 г. территория Мордовии частично входила в их состав. В Инсарском уезде малорусским владели 6 человек; белорусским - 28 человек; польским - 37 человек; латышским - 5 человек; немецким - 11 человек; еврейским - 3 человека. В более крупном по численности населении Краснослободском уезде малорусским владели больше людей - 354, но такая ситуация не являлась характерной для городов уезда, к примеру, в городе Краснослободск малорусским владели всего 3 человека, а в городе Троицк - 12 человек. В Саранском уезде были жители, владевшие малорусским, польским, белорусским, немецким, еврейским языками. В Симбирской губернии также наблюдалось владение чешским языком лицами мужского пола в количестве 6 человек. В Нижегородской губернии в группе «Остальные индоевропейские наречия» зафиксировано 40 человек, владевших цыганским языком. Таким образом, первая положительная динамика неместного контингента в численности Мордовии прослеживается уже в Первой всеобщей переписи населения Российской империи.

События Первой мировой войны (1914-1918) между двумя коалициями: Германией и Австро-Венгрией - с одной стороны, Великобританией, Францией, Россией, Бельгией, Сербией и Черногорией - с другой, также внесли вклад в формирование полиэтничности региона, появились первые беженцы из прифронтовой полосы (Бакаев 2001: 211). В Саранском уезде на 1 января 1916 г. находилась 21427 беженцев из западных губерний (Терешина 2017). О периоде с 1916 и последующих годах вплоть до 1922 г. сохранились списки и сведения о количестве беженцев в уездах Пензенской губернии, ныне относящихся к Мордовии. Например, в Ардатовском уезде в 1916 г. находилась 1340 беженцев, из них 740 детей до 14 лет. В г. Ардатове размещалось 219 беженцев. В Краснослободском уезде к 22 марта 1916 г. насчитывалось до 4747 беженцев, из них 1068 мужчин, 1716 женщин и 1963 ребенка в возрасте до 14 лет. По этническому составу из беженцев в Краснослободском уезде больше всего проживало русских 3888 чел., второе место по численности занимали галичане - 717 чел. (Терешина 2017).

Значительное количество документов, содержащих данные о численности контингента Мордовии хранится в Центральном государственном архиве Республики Мордовия, сведения содержатся в протоколах, письмах, докладах, списках, удостоверениях, карточках. Так, согласно Спискам пленных и беженцев и сведениям о них, в Краснослободском уезде проживали беженцы из Польши, Литвы, Белоруссии, Украины, Эстонии. Всего в Краснослободском уезде находилось 1728 беженцев, мигрировавших из Польши, Литвы, Белоруссии, Галиции и Украины. В архивных документах в источниках, содержащих сведениях о беженцах на 1 марта 1919 г., оставшихся в пределах Старо-Девиченской волости указывается поляков в количестве всего 11 человек, галичан - 12 человек.

В 1913 году Краснослободский уезд состоял из 20 волостей, самая большая концентрация беженцев сосредоточилась в Тениковской волости - 204 человека, а в 
Урейской волости числилось 8 беженцев. Всего по всем волостям зафиксировано 1734 человека со статусом беженца.

В Саранский уезд Пензенской губернии, состоящий из 29 волостей на 1913 год, с 15 декабря 1918 г. по 15 января 1919 г. прибыли беженцы из Вилены, Лиды Виленской губернии, также есть персональные данные беженцев, прибывших из Гродно Гродненской губернии. Кроме того, в списках встречаются беженцы из Виленской, Ковенкской губерний со следующими фамилиями: Крот А., Раковская В.К., а также поименованные члены их семей: Вацлав, София, Бронислав, Маря (Вилен. губ.); Мазур Юзефа Андреевна и дети Мария, Станислав, Антон, Франческа; Клвинь Вильгельм (Курл. губ.), Жмуцкий И.А. (Ковенской губ.), Почебут С.А., и жена Любовь (Волковыск Прозоровской вол.) и др.

В Саранском уезде, согласно ведомости «О числе осевших беженцев» от 15 марта 1918 г., проживали русские, поляки, латыши, евреи и прочие, всего в количестве 2996 человек, в т. ч. поляков - 166 человек, латышей соответственно - 102, евреев 479, прочих - 176 человек. Из них: всего мужчин - 804 человека, женщин - 910 человек, детей - 882 человека (16 01.1919 г.).

В целях идентификации личности, беженцу выдавалась именная карточка, содержащая данные о дате прибытия, ФИО, национальности, религии, родственном отношении к главе семьи, сведения о детях с указанием их имен. Например, среди личных карточек пленных и беженцев, прибывших в Саранский уезд, доступных в материалах архива, указана некая Анна Петровна Сушко, с местом жительства в деревне Чемеры, Чемерыкской волости Слоним. уезда, Гродненской губ. Позже карточки были заменены на удостоверения беженцев, по которым можно проследить географию их выезда в города, волости и уезды. Например, в удостоверении от 11 сентября 1918 г. № 78 написано, что оно выдано Саранской коллегией по делам пленных и беженцев гражданину Вульфу Уохелеву Уоффе 45-ти лет с полным указанием членов его семьи или, например, в удостоверении, выданном С. П. Шебжешень, сказано, что ему 23 года и что он из Холмской губернии, проживает в селе Посоп.

Государство в условиях наплыва беженцев стало принимать меры по их социальной адаптации в регионе. Например, как видно из доклада Саранского уездного комитета по призрению беженцев 1916 г., изначально беженцев расселяли на общих квартирах (Терешина 2017), позже было принято решение о переселении их на частные квартиры. Так, в докладе Комиссией «По изысканию упорядочения квартирного вопроса» сообщалось собранию членов Комитета о необходимости посодействовать беженцам, осевшим в городе Саранске, в переселении из общих квартир в частные и в благоустройстве своего хозяйства. Обязанность по поиску подходящих для проживания квартир полностью ложилась на беженцев. Комитетом поощрялось переселение беженцев из общих домов на частные квартиры, так как подразумевалось, что, будучи более самостоятельным и отчасти уже предоставленным самому себе, беженец скорее найдет обеспечивающий его семью заработок и таким образом перестанет быть бременем для государства.

В содержащемся в материалах архива Протоколе заседаний правления Саранского уездного комитета по призрению беженцев и выписке из заседаний Саранской уездной земской Управы также указываются меры поддержки беженцев, которые заключались в найме их для сельскохозяйственных работ. Вышеперечисленные действия сближали беженцев с местным населением и позволяли им закрепиться в регионе. 
Широкий спектр документов военного времени свидетельствует о пребывании военнопленных на территории Мордовского края (Терешина 2017). Так, в годы Первой мировой войны ряд населенных пунктов Мордовии стал местами постоянного водворения военнопленных. Например, в Ардатове на 1.1.1916 содержалось 65 офицеров и 751 чел. нижних чинов, в Саранске - 30 офицеров и 332 чел. нижних чинов (Бакаев 2001: 211). Из-за нехватки рабочей силы военнопленные, при их согласии, привлекались к труду (Терешина 2017). Например, в архивных материалах содержится письмо от 25 ноября 1915 г. № 295 в Совет Представителей Кооперативов, в Комитет по призрению беженцев, в котором указывалась необходимость в срочном порядке предоставить списочный состав трудоспособных беженцев-мужчин в возрасте от 17 до 55 лет включительно, и сообщить среди них количество лиц, желающих остаться работать в районе в зимнее время. Иностранные военнопленные в количестве 2518 человек в начале 1916 работали на строительстве Московско-Казанской железной дороги, среди них было 2108 австрийцев, 200 немцев, 159 славян, 42 румына, 9 военнопленных турецкой армии (христиан). Так же многие военнопленные привлекались к работе на промышленных предприятиях (Бакаев 2001: 211). Трудоспособные беженцы и военнопленные, прибывшие в Республику Мордовию, должны были работать, иначе они лишались продовольственного обеспечения.

В начале 1920-хх гг., когда началась реэвакуация беженцев и военнопленных, многие из них принимали решение остаться в мордовском крае и получали подданство. В России до 1917 г. не существовало единого нормативного акта, регулировавшего отношения подданства, гражданства.

Рассмотрим различные трактовки понятия подданства и гражданства, которые были сформулированы русскими правоведами. Отметим, что многие специалисты не проводили различий между этими понятиями. К примеру, Н.О. Куплеваский определял подданство или гражданство во взаимосвязи отдельного лица с определенной страной и ее правительством, основанной на обязанности «верности» и «подчинения» (Куплеваский 1902: 134). Ф.Ф. Кокошкин рассматривал подданство (гражданство) в тесной взаимосвязи к населению как к основному элементу государства. Таким образом, поданные (граждане) должны были подчиняться власти государства, не исключением были и иностранные граждане.

В архивных материалах содержатся именные данные иностранцев, получивших русское подданство в республике, например, в Списках служащих отделов Темниковского исполкома Совета народного хозяйства указаны 3 чеха, 3 мадьяра Австрийского подданства, в возрасте 21-37 лет: австрийский подданный австриец - Антонович Власов приписанный к Русскому подданству 30-ти лет, австрийский подданный итальянец мужчина 25-ти лет - Карабинин, который принял Русское подданство, или, например, испанское семейство состоящее из трех членов семьи: Фридриха 45 лет, жены 46 лет и Пенитье 15 лет, которые приняли русское подданство.

До настоящего времени в селе Журавкино Зубово-Полянского района, проживают внуки одного из подданных Австро-Венгерской империи. Внуки со слов отца воспроизводили воспоминания о своем деде - Эдварде Пуце, как о подданном Австро-Венгерской империи, который воевал против России во время Первой мировой войны. Дед был ранен и попал в плен в селе Журавкино, благодаря лечению и заботе местной девушки, которая ежедневно преодолевала порядка 20 верст, чтобы ухаживать за ним быстро пошел на поправку. В 1918 году после заключения с Германией 
Брестского мира, по условиям которого все пленные могли вернуться на родину, Эдвард Пуц уклонился от посадки в эшелон и остался в селе Журавкино, несмотря на уговоры своих товарищей. Эдвард Пуц принял православие, получил при крещении имя Мартын, обвенчался с Аленой Булдыжевой и построил для своей семьи дом на окраине села Журавкино. За время жизни в России Пуц не посетил ни одного города. В селе жил тихо и незаметно. Никогда не высказывал сожалении по поводу того, что остался жить в России. Родственники сохранили австрийский паспорт, в котором было записано место его рождения - город Вена, Австрия (Резепов 2014: 79).

В Протоколе заседания съезда уездных уполномоченных Пензенской Коллегии пленных от 25 января 1919 г. в повестке дня одного из рассматриваемых вопросов значится: «Реэвакуация беженцев». Во втором полугодии 1922 г. ликвидации подверглись уже эвакопункты. В связи с ликвидацией Центрэвака и его органов на местах оформление документов на выезд за границу беженцев Первой мировой войны был возложен на отделы управления губисполкомов. С января 1923 г. Центрэвак перестал существовать, но в Наркомате внутренних дел имелся эвакуационный отдел. Процесс оформления документов включал в себя визирование списков беженцев для выезда из России с иностранными делегациями (Польской, Латвийской, Литовской, Эстонской) для въезда в соответствующую страну (Белова 2012: 38-45). Исследователь Н.В. Лазарева отмечает, что в мае 1925 г. репатриация беженцев Первой мировой войны была официально завершена, а не выехавшие без уважительной причины беженцы теряли свой статус, так как объявлялись советскими гражданами (Лазарев 1999). Возможно, что виды на жительство выдавались и раньше. Например, «В Ардатовский уездный отдел Управления на № 8358 от 31/1. вх. № 328. Губотдел Управления разъясняет, что военнопленные и беженцы состоят на учете в органах Центроэвака по месту жительства, откуда и получают соответствующие удостоверения служащие им видом на жительство, - а потому в сведениях о иностранцах, проживающих в пределах уезда надлежит давать сведения только о тех иностранцах, кои имеют виды на жительство для иностранцев, согласно инструкции Народного комиссариата внутренних дел (далее НКВД) № 53. «При сем прилагается копия просимого циркуляра. Заведующий Г.О.У. (роспись). Заведующий Инотделением (подпись)». 1921 год. № 262. Копия. Циркулярно. Всем ГУБОТУПРАВАМ по Административному /общему/П/отделу. Копия Начгубэвакам. В разъяснение параграфа 13 инструкции о выдаче видов на жительство иностранным гражданам в РСФСР 14 февраля с/г. № 53 НКВД сообщается: 1. Военнопленным - желающим ехать на родину никаких временных удостоверений не давать. Видом на жительство для них является удостоверение ЭВАКОВ. 2. а/ Беженцы должны получать виды на жительство установленные для граждан РСФСР / паспорта или трудкнижки».

Современный исследователь, краевед А.В. Лютов (Краснослободск, Мордовия) в своих изысканиях пишет: «Во время Первой мировой войны «Военнопленных в городе Краснослободске было почти полторы сотни - немцев, австрийцев, венгров, этапированных к месту ссылки. Работая с Метрическими книгами церквей за 19151916 годы, в разделе «Умершие» я наткнулся на иностранные фамилии, нетипичные для жителей города. Это и оказались пленные, навечно оставшиеся в краснослободской земле. Во время войны (до 1918 года) они оставались в нашем городе. Некоторые из них приняли православие и женились на краснослободских девушках» (Лютов 2019: 208). 
В начале XX в. на территории Приволжского федерального округ начался процесс формирования мордовской государственного устройства, который состоял из четырех этапов. Первый этап, охватывающий период с 1918 по 1928 гг., знаменателен тем что 13 мордовских волостей и 377 местных органов власти (сельских советов) были созданы в Пензенской, Ульяновской, Нижегородской губерниях. Во время первого этапа, в 1926 г., проходила Всероссийская перепись населения, согласно которой на территории Мордовии проживали 1 млн. 340 тыс. человек, из которых мордва насчитывала 427607 чел. (32,2\%), русские - 839218 (63,2\%), татары - 59917 (4,5\%). Данные переписи 1926 года представлены только по губерниям и не содержат информацию по народностям и владению родным языком в уездах. В 1928 г. начинался второй этап, который связан с районированием Среднего Поволжья и образованием в составе Средневолжской области Саранского округа, переименованного в том же году в Мордовский. На третьем этапе в 1930 году, Мордовский округ был преобразован в Мордовскую автономную область, что определялось Постановлением Президиуму ВЦИК от 10 января 1930. На четвертом этапе в 1934 году, произошло преобразование Мордовской автономной области в Мордовскую Автономную Советскую Социалистическую Республику и ее включение в состав Российской Федерации.

Согласно данным всесоюзной переписи населения 1939 года, накануне Отечественной войны на территории Мордовии проживали представители разных народов, наиболее многочисленные среди них: украинцы, белорусы, грузины, азербайджанцы, армяне, узбеки, туркмены, казахи, киргизы, немцы, евреи, молдаване, цыгане, болгары, греки, иранцы, китайцы, корейцы, латыши, литовцы, поляки, румыны, эстонцы. Можем предположить, что какая-то часть их является потомками событий конца XIX - нач. XX вв.

$$
* * *
$$

Значимыми для формирования структуры населения Приволжского федерального округа историческими событиями были Первая мировая война и связанные с ней переселения из западных стран, организация и расположение в крае лагерей для военнопленных, развитие промышленности. Перечисленные обстоятельства оказали влияние на расширение географии иностранного контингента в республике Мордовия и изменение динамики их численности. На основе архивных материалов, хранящихся в центральном государственном архиве Республики Мордовия, авторам удалось получить новые данные о беженцах и военнопленных из прифронтовой зоны. Важным источником в этом плане оказались документы, удостоверяющие личность беженца: от карточек до удостоверений, в которых указывались личностные данные прибывшего и членов его семьи, а также представлены их персональные данные.

К началу 20 -хх гг. когда началась реэвакуация беженцев и военнопленных, многие из них приняли решение остаться в мордовском крае и получали российское подданство. Представленное исследование, основанное на архивных материалах, вводимых впервые в научный оборот, публикациях ученых, статистических данных, отраженных в переписях населения, позволяет утверждать, что созданные государством благоприятные социальные условия для беженцев и военнопленных в мордовском крае, способствовали их закреплению в регионе. Процесс формирования мордовской государственности и ее включение в состав субъектов Российской Фе- 
дерации складывался исторически в силу разных факторов и событий второй половины XIX - начала XX в., они же сыграли ключевую роль в формировании состава населения Мордовии, который характеризуется своей полиэтничностью.

Анализ данных переписей указывает на положительный прирост иностранного контингента в республике. Согласно статистическим данным переписи населения Российской империи 1897 года, в Мордовии были жители, владевшие белорусским, малорусским, польским, латышским, немецким, еврейским, чешским, цыганским языками. Накануне Отечественной войны, согласно данным всесоюзной переписи населения 1939 года, на ее территории проживали такие народы как: украинцы, белорусы, грузины, азербайджанцы, армяне, узбеки, туркмены, казахи, киргизы, немцы, евреи, молдаване, цыгане, болгары, греки, иранцы, китайцы, корейцы, латыши, литовцы, поляки, румыны, эстонцы.

Авторы пришли к выводу, что значимыми историческими обстоятельствами, оказавшими влияние на этнический состав населения региона, являются события империалистической войны, такие как приток беженцев из западных стран, организация и расположение лагерей с военнопленными на территории Мордовии и др.

\section{Источники и материалы}

ЦГА РМ. Ф. Р-23 - Центральный государственный архив Республики Мордовия. Ф. Р-23. Оп. 1. Д. 5 Приказы, циркуляры, распоряжения и постановления, распоряжения и постановления Центральной и Пензенской губернской Коллегий и беженцев.

ЦГА РМ. Ф. Р-62 - Центральный государственный архив Республики Мордовия. Ф. Р-62. Оп. 1. Д. 37. Списки служащих отделов Темниковскогоуисполкома Совета народного хозяйства. Сведения об иностранцах, проживающих в уезде.

ЦГА РМ. Ф. Р-56 - Центральный государственный архив Республики Мордовия. Ф. Р-56 Оп. 1. Д. 8. Саранская уездная земская Управа. Протоколы заседаний правления Саранского уездного комитета по призрению беженцев и выписка из заседаний; переписка Саранского Совета представителей кооперативов с уездным комитетом по призрению беженцев.

ЦГА РМ. Ф. Р-334 - Центральный государственный архив Республики Мордовия. Ф. Р-334. Оп.1. Д. 1. Удостоверения выданные Саранской уездной коллегией по делам пленных и беженцев для удостоверения личности и выезда на родину.

ЦГА РМ. Ф. Р-334 - Центральный государственный архив Республики Мордовия. Ф. Р-334. Оп. 1. Д. 2. Переписка Саранской уездной коллегии с Пензенской губернской коллегией по делам пленных и беженцев. Списки и личные карточки пленных и беженцев, прибывших в Саранский уезд.

ЦГА РМ. Ф.Р-23 - Центральный государственный архив Республики Мордовия. Ф.Р-23. Оп. 1. Д.6. Списки пленных и беженцев и сведения о них по Краснослободскому уезду. Переписка Краснослослободской уездной комиссии Пленбежа и Губернским Пленбежем, волсоветами и исполкомом.

\section{Научная литература}

Бакаев Е.И. Военнопленные // Мордовия / Энциклопедия в 2 т. Т. 1: А - М. Мордов. кн. издво, 2001. С. $211-212$.

Белова И.Б. Заключительный этап реэвакуации беженцев Первой мировой войны из Советской России в 1922-1923 гг.// Российский историко-архивоведческий журнал «Вестник Архивиста». 2012. С. 38-45.

Гетрелл П. Беженцы в России в годы Первой мировой войны // Исторические записки. 2001. № 4. C. $46-72$. 
Копылов В. Р. Иностранные трудящиеся в России в период нарастания революционного кризиса и Февральской революции (октябрь 1916 - март 1917) // Общие закономерности и особенности развития России в период империализма. М.; Л., 1977. С. 61-69.

Куплеваский Н.О. Российское государственное право. №1. 1902. С.134.

Куриев А. Н. Беженцы Первой мировой войны в России // Вопросы истории. 1999. № 8.

Лазарева Н.В. Судьба беженцев Первой мировой войны в Советской России: 1918-19 гг.: На примере Курской губернии: дисс. ... канд. ист. наук. Курск, 1999.

Ломшин В. А., Разживин В.Ф. Перепись населения. Энциклопедия Мордовии. 2007. Т. 2 C. $159-160$.

Лютов А. Легенды и предания краснослободского края: Записки историка. - Саранск : Изд. Константин Шапкарин, 2019. - 320 с.

Никонова Л. И. Мордовия в этнокультурном пространстве: к постановке проблемы // Этнокультурное образование: Опыт и перспективы. - Саранск, 2007. - С. 19. - 21.

Ниманов И.Б. Особенности и основные факторы содержания и хозяйственной деятельности военнопленных в 1914-1917 годах в Поволжье тема диссертации и автореферата по ВАК РФ 07.00.02, кандидат исторических наук. М., 2009.

Петербургский И.М., Шитов В.Н., Заварюхин Н.В., Кадерова Т.Н., Тувин А.С., Абрамов В.К. и др. История // Мордовия: Энциклопедия в 2 т. Т. 1: А-М /Гл. редкол. А. И. Сухарев (Гл. ред.), В. А. Юрченков (зам. Гл. ред.); Саранск: Мордов. кн. изд-во, 2003. - С. 25-44.

Резепов Е. Храбрый портной // Русский мир. Апрель. 2014. С. 72 -79.

Терешина Н. Н. Мордовский край в годы первой мировой войны (по документам Центрального государственного архива Республики Мордовия) // XX век и Россия: общество, реформы, революции [Электронный ресурс]: электрон. сб. Вып 5. - Электрон. дан. - Самара, 2017.

Хасин В.В. Миграционные процессы в Российской империи в Первую мировую войну (по документам Нижнего Поволжья): автореф. дисс. ... канд. ист. наук. Саратов, 1999

Gurko, A., Oparina, S., Vasyutkina, L., \& Potekhina, E. The environmental investments justification. E3S Web of Conferences, 91(0), EDP Sciences, 1-8. 2019. https://doi.org/10.1051/ e3sconf/201991080 TPACEE-2018 8029.29

Nikonova, Lyudmila I., and Albina I. Minakova

\section{Migration Factor in the Formation of the Multi-Ethnic Population of Mordovia: A Historical Aspect}

DOI: $10.33876 / 2311-0546 / 2021-54-2 / 230-240$

Based on mainly unpublished and previously unstudied sources, the article shows the role of foreign peoples in the formation of the multi-ethnic population of Mordovia, being part of the Volga Federal District of the Russian Federation. The origins of the formation of multi-ethnicity of Mordovia are revealed, the main trends in the development of migration processes are described. Based on the previous scientific findings and state statistics, the spatial mobility of the population of Mordovia from the second half of the 19th century to the beginning of the 20th century are considered. The data of the Russian Census, according to which people of 119 nationalities lived in Mordovia in 2010, confirms the complexity of the population of the republic. The paper covers the data of the First Census of the Russian Empire in 1897 with a foreign contingent in the provinces of Mordovia and the 1939 Census. The authors found that the multi-ethnic population of the Mordovian Republic was formed under the influence of the most important historical events that took place both in Europe and in Russia. These events gave rise to processes that contributed to migration flows and changed the ethnic composition of the population of Mordovia. For example, the construction of the Kazan railway, which required the influx of foreign specialists and 
equipment maintenance workers in the Volga Federal District, the events of World War I, which caused a refugee flow from Western countries to the regions of Russia, the location of prisoner-of-war camps in the Republic, marriage migrations etc. The authors provide a historical outline on how foreigners in Mordovia acquired Russian citizenship.

Keywords: multi-ethnic region, ethnic structure, refugees, national composition, foreign nations, population, migration

For Citation: Nikonova L.I., and A.I. Minakova 2021. Migration Factor in the Formation of the Multi-Ethnic Population of Mordovia: A Historical Aspect. Herald of Anthropology (Vestnik Antropologii) 2: 230-240.

\section{Author Info:}

Nikonova, Lyudmila I. - Dr., Prof., Senior Resercher, Institute for Humanities Studies under the Government of the Republic of Mordovia (Saransk, Russian Federation). E-mail: congress7@list.ru. ORCID: htpps://orcid.org/0000-0003-4327-9534

Minakova, Albina I. - Senior Lecturer, Bauman Moscow State Technical University (Moscow, Russian Federation). E-mail: mau@bmstu.ru. ORCID: htpps://orcid.org/00000003-3938-7276

\section{References}

Bakaev, E.I. 2001. Voyennoplennyye. [Prisoners of war]. In A.I. Suharev \& V.A. Urchenkov (Eds.), Entsiklopediya of Mordovii 1, $211-212$.

Belova, I. B. 2012. Zaklyuchitel'nyy etap reevakuatsii bezhentsev Pervoy mirovoy voyny iz Sovetskoy Rossii v 1922-1923 Gg. [The final stage of the re-evacuation of the refugees of the First World War from Soviet Russia in 1922-1923 Gg]. Russian historical and archival journal Bulletin of the Archivist, 116, Russian State Humanitarian University, 38-45.

Filobokova, L. 2018. The model of governance of food security and agro-industrial complex of Russia in conditions of globalization. Conf. Series: Earth and Environmental Science 274 (1), IOP Publishing Ltd, 1-5.

Getrell, P. 2001. Bezhentsy v Rossii v gody Pervoy mirovoy voyny [Refugees in Russia during the First World War]. Historical notes 4 (122): 46-72

Grech, H. 2019. Impact of forced migration on communication and social adaptation. Folia Phoniatrica et Logopaedica 71 (4), S. Karger AG, 137-145. Doi: 10.1159/000497057

Gurko, A., Oparina, S., Vasyutkina, L., \& Potekhina, E. 2019. The environmental investments justification. E3S Web of Conferences, 91(0), EDP Sciences, 1-8. https://doi.org/10.1051/ e3sconf/201991080 TPACEE-2018 8029.29

Kopylov, V.P. 1977. Inostrannyye trudyashchiyesya v Rossii v period narastaniya revolyutsionnogo krizisa i Fevral'skoy revolyutsii (oktyabr' 1916 - mart 1917) [Foreign workers in Russia during the growing revolutionary crisis and the February Revolution (October 1916 - March 1917)]. General patterns and features of the development of Russia in the period of imperialism 1: 61-69.

Kuplevaskiy, N.O. 1902. Russkoye gosudarstvennoye pravo [Russian state law]. Vol. 1, 134.

Khasin, V.V. 1999. Migratsionnyye protsessy v Rossiyskoy imperii v Pervoy mirovoy voyne [Migration processes in the Russian Empire in the First World War:]. Saratov. (Doctoral dissertation).

Kurtsev, A.N. 1999. Bezhentsy pervoy mirovoy voyny v Rossii (1914-1917 gg.) [Refugees of the First World War in Russia (1914-1917)]. Voprosi istorii [Questions of history]. Vol. 8.

Lazareva, N.B. 1999. Sud'ba bezhentsev Pervoy mirovoy voyny v Sovetskoy Rossii: 1918-19 gg.: Na primere Kurskoy gubernii [The Fate of the Homeless People of World War I in Soviet Russia: 
1918-19 ${ }^{\text {th }}$ : At the premiere of Kursk Province] (Doctoral dissertation).

Lomshin, V.A., \& Razzhivin, V.F. 2007. Perepis' naseleniya. [Population census]. In Entsiklopediya of Mordovii, edited by A.I. Suharev \& V.A. Urchenkov. Vol. 2, 159-160.

Lyutov, A.V. 2019. Legendy i predaniya Krasnoslobodskogo kraya. Zapiski istorika. [Legends and traditions of the Krasnoslobodsky Territory. Notes of the historian]. Saransk: Izdatel'Konstantin Shapkarin. p. 320.

Nikonova, L.I. 2007. Mordoviya v etnokul'turnom prostranstve: $\mathrm{k}$ postanovke problem [Mordovia in the ethnocultural space: to the formulation of problems]. Interaktivplus 5: 19-21.

Nimanov, I.B. 2009. Osobennosti i osnovnyye faktory soderzhaniya i khozyaystvennoy deyatel'nosti voyennoplennykh $v$ 1914-1917 godakh v Povolzh'ye [Features and main factors of the maintenance and economic activity of prisoners of war in 1914-1917 in the Volga region] (Doctoral dissertation).

Peterburgskiy, I. M., Shitov, V. N., Zavaryukhin, N. V., Kaderova, T. N., Tuvin, A.S., Abramov, V.K. 2003. Istoriya [History]. In Entsiklopediya of Mordovii, edited by A.I. Suharev \& V.A. Urchenkov. Vol. 1, 25-44.

Rezepov,Ye. 2014. Khrabryy portnoy [Brave tailor]. Russkiy mir 28 (12): $72-79$.

Tereshina, N.N. 2017. The Mordovian Territory during the First World War (according to the documents of the Central State Archive of the Republic of Mordovia) [The Mordovian Territory during the First World War (according to the documents of the Central State Archive of the Republic of Mordovia)]. XX Century and Russia: society, reforms, revolutions, 5. 